\title{
Ruminal degradation and intestinal digestibility of protein and amino acids in high-protein feedstuffs commonly used in dairy diets
}

\author{
H. A. Paz, ${ }^{* 1}$ T. J. Klopfenstein, ${ }^{*}$ D. Hostetler, ${ }^{*}$ S. C. Fernando, ${ }^{*}$ E. Castillo-Lopez, $†$ and P. J. Kononoff*2 \\ *Department of Animal Science, University of Nebraska-Lincoln, Lincoln 68583 \\ †Department of Animal and Poultry Science, University of Saskatchewan, Saskatoon, Canada S7N 5A8
}

\begin{abstract}
A study was conducted to determine the rumen degradation and intestinal digestibility of crude protein (CP) and AA, and AA composition of the rumen-undegradable protein (RUP) from 3 sources of blood meal (BM1, BM2, and BM3), canola meal (CM), low-fat distillers dried grains with solubles (LFDG), soybean meal (SBM), and expeller soybean meal (ESBM). Two Holstein cows fitted with ruminal and proximal duodenal cannulas were used for in situ incubation of $16 \mathrm{~h}$ and for the mobile bag technique. To correct for bacterial contamination of the RUP, 2 methods were used: purines and DNA as bacterial markers. Ruminal degradations of $\mathrm{CP}$ were $85.3,29.8,40.7,75.7,76.9,68.8$, and 37.0 $\pm 3.93 \%$ for BM1, BM2, BM3, CM, LFDG, SBM, and ESBM, respectively. Ruminal degradation of both total essential AA and nonessential AA followed a similar pattern to that of $\mathrm{CP}$ across feedstuffs. Based on the ratio of AA concentration in the RUP to AA concentration in the original feedstuff, ruminal incubation decreased (ratio <1) the concentrations of His, Lys, and Trp, and increased (ratio $>1$ ) the concentrations of Ile and Met across feedstuffs. Compared with purines, the use of DNA as bacterial marker resulted in a higher estimate of bacterial CP contamination for $\mathrm{CM}$ and lower estimates for LFDG and ESBM. Intestinal digestibility of RUP could not be estimated for BM1, BM3, and SBM due to insufficient recovery of residue. For the remaining feedstuffs, intestinal digestibility of RUP was highest for ESBM, followed by BM2 and LFDG, and lowest for CM: $98.8,87.9,89.7$, and $72.4 \pm 1.40 \%$, respectively. Intestinal absorbable dietary protein was higher for BM2 compared with CM and LFDG, at 61.7, 17.9 , and $20.7 \pm 2.73 \% \mathrm{CP}$, respectively. As prices fluctuate, intestinal absorbable protein or AA may be used as a tool to aid in the selection among feedstuffs with different protein quality.
\end{abstract}

Received March 4, 2014

Accepted June 23, 2014.

${ }^{1}$ Current affiliation: Grain States Soya Inc., West Point, NE 68788.

${ }^{2}$ Corresponding author: pkononoff2@unl.edu
Key words: rumen degradation, intestinal digestibility, amino acid, bacterial crude protein contamination

\section{INTRODUCTION}

Great interest has emerged in balancing dairy cattle diets for AA due to the potential benefits to increase milk protein and improve $\mathrm{N}$ efficiency ( $\mathrm{N}$ in milk: $\mathrm{N}$ intake) and, as a result, increase farm profitability and decrease environmental impacts (Schwab, 2010). Ruminal microbial CP, RUP, and endogenous proteins contribute to the AA supply that will be available for absorption at the small intestine of the dairy cow. To meet the AA demands of high-producing cows, a sufficient amount of RUP has to complement the AA supplied by microbial CP and endogenous sources (NRC, 2001). In addition, studies have shown that an optimum AA profile in the RUP positively affects milk protein (Schwab et al., 1992; Guinard and Rulquin, 1994). The dairy NRC (2001) model assumes a similar AA profile between the RUP of a feedstuff and the original feedstuff and also a similar digestibility between the RUP and individual AA in the RUP. However, studies have shown that these assumptions may not always hold true (Mjoun et al., 2010; Maxin et al., 2013). Compared with the original feedstuff, the Cornell Net Carbohydrate and Protein System (CNCPS) model (v6.1; http://www.cncps.cornell.edu/) assigns a different AA profile to the estimated RUP based on the AA profile of the buffer-insoluble protein (O'Connor et al., 1993); however, this procedure does not account for AA in the soluble fraction, is analytically challenging, and default values are not routinely updated (Van Amburgh et al., 2013). In order for feeding strategies targeted to balance for AA to be successful, models need to accurately estimate the RUP of feedstuffs and the profile and digestibilities of individual AA in the RUP.

The dairy NRC (2001) recommends the use of the in situ procedure to estimate ruminal degradation of $\mathrm{CP}$ from feedstuffs. This procedure requires the incubation of a feedstuff sample and recovery of the feedstuff residue within porous bags in the rumen. To avoid errors associated with bacterial contamination, bags 
are washed in an attempt to free the feedstuff residue from ruminal bacteria. However, bacterial contamination may still remain (Beckers et al., 1995). Purines (adenine and guanine) have commonly been used as markers (Broderick and Merchen, 1992) to correct for bacterial contamination; however, purines originating from the feedstuff residue may affect the accuracy of these markers. The use of genetic markers may increase specificity as a means to estimate bacterial contamination. Although DNA has been used as a marker for microbial protein flow in the duodenum (Belanche et al., 2011; Castillo-Lopez et al., 2013), the use of this marker to correct for bacterial contamination in in situ studies has not been explored. The main objectives of this study were to determine the rumen degradation of $\mathrm{CP}$ and $\mathrm{AA}$ and the AA composition of RUP using the in situ technique and to determine the intestinal digestibility of $\mathrm{CP}$ and AA using the mobile bag technique from several feedstuffs used as protein supplements in dairy diets and to evaluate the use of DNA as a marker to correct for bacterial CP (BCP) contamination.

\section{MATERIALS AND METHODS}

\section{Feedstuffs}

Feedstuffs evaluated in this experiment included 3 sources of blood meal (BM1, BM2, and BM3), canola meal (CM), low-fat distillers dried grains with solubles (LFDG; Poet Nutrition, Sioux Falls, SD), soybean meal (SBM), and expeller SBM (ESBM; SoyPlus, West Central, Ralston, IA). From the blood meals, BM1 was spray dried and BM2 and BM3 were ring dried. Over the course of approximately 6 mo, 5 different batches of each feedstuff were sampled for a total of 35 samples. These samples were collected from a feed mill operated by Intermountain Farmers Association (Salt Lake City, UT). All samples were ground to pass through a 2-mm screen using a Wiley mill (Arthur H. Thomas Co., Philadelphia, PA). Feedstuffs were analyzed for DM (AOAC International, 2000), N (Leco FP-528 N Combustion Analyzer; Leco Corp., St. Joseph, MI), NDF (Van Soest et al., 1991), ADF (method 973.18; AOAC International, 2000), sugar (DuBois et al., 1956), ether extract (method 2003.05; AOAC International, 2006), ash (method 942.05; AOAC International, 2000), and minerals (method 985.01; AOAC International, 2000) by Cumberland Valley Analytical Services Inc. (Hagerstown, MD). Additionally, feedstuffs were analyzed for AA (method 982.30 E; AOAC International, 2006) using a Hitachi L-8800 AA analyzer (Hitachi Co., Tokyo, Japan) by the Experimental Station Chemical Laboratories, University of Missouri-Columbia (Columbia, MO). Across feedstuffs, all analyses were done on ground samples except for particle size, where the geometric means of both the original and ground samples were determined following the American Society of Agricultural and Biological Engineers (ASABE, 2008) guidelines.

\section{Animals and In Situ and Mobile Bags}

Before conducting the experiment, all procedures using animals were approved by the University of Nebraska-Lincoln Institutional Animal Care and Use Committee. Two multiparous Holstein cows (BW of $660 \pm 33 \mathrm{~kg}$ ) fitted with flexible ruminal and proximal duodenal cannulas and with an average DIM of $210 \pm$ 17 and milk yield of $27.3 \pm 8.00 \mathrm{~kg}$ were used for the in situ and mobile bag procedures. Cows were housed in a temperature-controlled room in individual tiestalls with continuous access to water and fed once daily at 1000 $\mathrm{h}$. The ingredient composition of the diet (\% of DM) included $34.4 \%$ corn silage, $18.5 \%$ alfalfa hay, $16.0 \%$ ground corn, $16.5 \%$ soy products, $11.5 \%$ LFDG, $0.74 \%$ blood meal, and $2.36 \%$ minerals and vitamins supplement. The chemical composition of the diet (\% of DM) was $16.0 \% \mathrm{CP}, 35.3 \% \mathrm{NDF}$, and $3.70 \%$ fat. Ruminal degradations of $\mathrm{CP}$ and $\mathrm{AA}$ were determined in situ, and intestinal digestibilities of $\mathrm{CP}$ and AA were determined using the mobile bag technique. For each sample, approximately $1.5 \mathrm{~g}$ from each batch was weighed into 12 N-free polyester bags (R510, Ankom Technologies, Macedon, NY) with a mean pore size of $50 \mu \mathrm{m}$ and a dimension of $5 \times 10 \mathrm{~cm}$. Bags were heat-sealed using an Ankom Heat Sealer (Ankom Technologies) and then divided into mesh bags $(46 \times 38 \mathrm{~cm})$ that contained 2 secured $100-\mathrm{g}$ weights that were used to prevent bags from floating in the rumen mat. Each mesh bag contained 35 polyester bags so that all batches from every sample were present. At 1400 h, 6 mesh bags per cow were inserted through the rumen cannula, positioned in the ventral sac, and incubated for $16 \mathrm{~h}$. Following rumen incubation, all mesh bags were gently rinsed with cold water to remove particulate matter and to cease microbial activity. Polyester bags were removed from the mesh bags and half of the bags (referred to as rumen bags) from each sample per cow were immediately frozen $\left(-20^{\circ} \mathrm{C}\right)$ for later analysis. The remaining bags (referred to as mobile bags) were washed in a domestic washing machine using 5 cycles that consisted of a 1-min wash and 2-min spin. The previously described washing steps will be referred as the washing procedure throughout this paper. After washing, bags were used for the mobile bag procedure according to Kononoff et al. (2007). Mobile bags were incubated in a pepsin- $\mathrm{HCl}$ solution $(1 \mathrm{~g}$ of pepsin/L of $0.01 \mathrm{~N} \mathrm{HCl})$ for $3 \mathrm{~h}$ in a $39^{\circ} \mathrm{C}$ water bath with occasional stirring to simulate 
abomasal digestion. Following the pepsin- $\mathrm{HCl}$ incubation, mobile bags were rinsed with distilled water to wash out the pepsin- $\mathrm{HCl}$ solution and to force the residue to the bottom, and then the upper portion of the bag was tightly rolled. Subsequently, mobile bags were inserted through the duodenal cannula of each cow during 3 consecutive days (35 mobile bags/d) at a rate of 1 mobile bag every 5 min. Mobile bags were inserted through the duodenal cannula of the corresponding cow in which they were ruminally incubated, and insertion of mobile bags was spread over $3 \mathrm{~d}$ to avoid intestinal obstruction and maintain cow comfort. Once they had passed through the cow, mobile bags were retrieved from the manure from the appearance of the first bags (8 h after insertion) until $24 \mathrm{~h}$ after insertion, lightly rinsed with cold water to remove fecal material, and frozen $\left(-20^{\circ} \mathrm{C}\right)$ until all bags were recovered. Rumen and mobile bags were thawed and then washed following the washing procedure. Bags were then rinsed with distilled water to force all the residue to the bottom, rolled, and dried in a $100^{\circ} \mathrm{C}$ oven for $12 \mathrm{~h}$. Following drying, bags were weighed to determine the weight of the remaining residue. Rumen and mobile bag residues were, respectively, composited by sample, batch, and cow and then composites were divided into 2 subsamples. One set of subsamples was analyzed for $\mathrm{N}$ using the combustion method (AOAC International, 1996) in a combustion $\mathrm{N}$ analyzer (Leco FP-528; Leco Corp.) and the other set was analyzed for AA as described for feedstuffs. The in situ and mobile bag techniques share various potential sources of variation. Among them are sample size to bag surface ratio, bag pore size, animal effects, and washout of particles (Michalet-Doreau and Ould-Bah, 1992; Vanzant et al., 1998). Ideally, when using the mobile bag technique, bags should be recovered at the terminal ileum; however, for practical reasons, recovery of the bags in feces is more common and it is assumed that the effect of protein digestion in the large intestine is minor. Results of Vanhatalo and Varvikko (1995) suggest that fecal collection of bags may be of greater concern when evaluating feedstuffs with high fiber and low $\mathrm{N}$ concentrations and not corrected for BCP contamination.

\section{Calculations}

The RDP for all samples was determined as the portion of the $\mathrm{CP}$ that disappeared from the polyester bag following the in situ incubation. The RUP was calculated as 100 - RDP. The total-tract CP digestibility (TTCPD) was calculated as 100 - total-tract indigestible protein. The digestible portion of the RUP was assumed to be the percentage of the $\mathrm{CP}$ escaping ruminal disappearance but not recovered in the residue following intestinal incubation and was calculated as 100 - (total-tract indigestible protein/RUP).

\section{Correction for Bacterial CP Contamination}

During the last day of insertion of mobile bags, 6 additional mesh bags per cow, containing 35 polyester bags so that all batches from every sample were present, were incubated in the rumen for $16 \mathrm{~h}$. In addition, whole ruminal contents were collected for 2 consecutive days from 4 different locations within the rumen at 8000 and $1500 \mathrm{~h}$ on the first day and at 1000 and 1700 $\mathrm{h}$ on the second day. Following incubation, bags were washed following the washing procedure.

Isolation of Ruminal Bacteria. Ruminal bacteria were isolated following the procedure described by Hristov et al. (2005). Whole ruminal contents were composited by cow and squeezed through 2 layers of cheesecloth and the filtrate was retained. Solids remaining on the cheesecloth were added to a volume of cold buffer (McDougall, 1948) equal to the volume of filtrate and shaken manually in a screw-capped jar to dislodge the ruminal microorganisms loosely associated with feedstuff particles. This suspension was then squeezed through 2 layers of cheesecloth, and the 2 filtrates were combined in similar proportion and preserved with $5 \%$ (vol/vol) formalin. From this sample, bacteria were harvested via differential centrifugation (Hristov and Broderick, 1996) with an initial low-speed centrifugation at $400 \times g$ for 5 min at $4^{\circ} \mathrm{C}$ and a subsequent highspeed centrifugation at $20,000 \times g$ for 15 min at $4^{\circ} \mathrm{C}$. Samples were maintained on ice while being processed. The supernatant was then discarded and the isolated bacterial pellets were composited by cow and frozen at $-20^{\circ} \mathrm{C}$ for later analysis. Bacterial pellets were thawed and then lyophilized (Freezemobile 25SL, VirTis, Gardiner, NY). Dried bacterial samples were ground with a mortar and pestle and a subsample was analyzed for N (Leco FP-528 N Combustion Analyzer; Leco Corp.) and other subsample was analyzed for AA as described for feedstuffs.

Bacterial $N$ Using Purines as Bacterial Marker. Rumen bag residues and lyophilized bacterial samples were analyzed for purines as described by Makkar and Becker (1999). Briefly, $75 \mathrm{mg}$ of rumen bag residue or $50 \mathrm{mg}$ of lyophilized bacterial sample was placed into Pyrex screw-cap tubes and mixed with 0.5 $\mathrm{mL}$ of $3 \mathrm{~m} M$ allopurinol internal standard solution and $2.5 \mathrm{~mL}$ of $0.6 \mathrm{M} \mathrm{HClO}_{4}$ and then incubated in a water bath $\left(90-95^{\circ} \mathrm{C}\right)$ for $1 \mathrm{~h}$. After cooling, $7.5 \mathrm{~mL}$ of 10 $\mathrm{m} M \mathrm{NH}_{4} \mathrm{H}_{2} \mathrm{PO}_{4}$ was added to all samples and $\mathrm{pH}$ was adjusted to between 6.6 and 6.9 with $8 \mathrm{M} \mathrm{KOH}$. Then, samples were centrifuged at $3,000 \times g$, filtered through a 13 -mm disposable syringe filter $(0.45 \mu \mathrm{m})$ with GHP 
(hydrophilic polypropylene) membrane into an HPLC vial, and analyzed for total purines using a 717 HPLC system (Waters Corp., Milford, MA). Calculation of bacterial $\mathrm{N}$ was based on the ratio purine: $\mathrm{N}$ obtained from the lyophilized bacterial sample and the concentration of purines in the rumen bag residues. Bacterial $\mathrm{N}$ was multiplied times 6.25 to obtained BCP.

Bacterial N Using DNA as Bacterial Marker. For both rumen bag residues and lyophilized bacterial samples, bacterial DNA was extracted using the repeated beat beading plus column method based on the extraction method for PCR-quality DNA from digesta samples described by Yu and Morrison (2004). Rumen bag residues and lyophilized bacterial samples were mixed with lysis buffer and zirconia beads and then shaken to physically disrupt the cells and expose the cell contents. Then, nucleic acids were precipitated and DNA was purified by a series of centrifugation steps that removed RNA and proteins. The concentration of DNA in the samples was measured by spectrophotometry (ND-1000 Spectrophotometer, NanoDrop Technologies Inc., Wilmington, DE), and the samples were stored at $-20^{\circ} \mathrm{C}$ in aliquots of $25 \mu \mathrm{L}$ for later analysis of $\mathrm{BCP}$ using real-time PCR.

The bacterial DNA marker used in this study has been reported elsewhere (Yu et al., 2005; Castillo-Lopez et al., 2013); it is part of the gene encoding the $16 \mathrm{~S}$ rRNA, which has been shown to be highly preserved in bacteria (Ogier et al., 2002; Zimmermann et al., 2010). The National Center of Biotechnology Information (NCBI) accession number of the targeted bacterial DNA marker is FJ715623. The marker is composed of a forward primer, a TaqMan probe, and a reverse primer, as follows: forward primer: 5 '-act cet acg gga ggc agc ag-3'; TaqMan probe: $5^{\prime}-\mathrm{FAM} / \mathrm{tgc}$ cag cag ccg cgg taa tac/TAMRA-3'; reverse primer: 5 '-gac tac cag ggt atc taa tcc- $3^{\prime}$.

Real-time PCR reactions were as follows: $4 \mu \mathrm{L}$ of DNA sample was combined with $1 \mu \mathrm{L}$ of $10 \mu M$ forward primer, $1 \mu \mathrm{L}$ of $10 \mu \mathrm{M}$ reverse primer, $0.25 \mu \mathrm{L}$ of $10 \mu M$ TaqMan probe, $7.5 \mu \mathrm{L}$ of TaqMan Master Mix (Applied Biosystems, Foster City, CA), and $1.25 \mu \mathrm{L}$ of nanopure water. Two samples with no DNA were included and used as nontemplate controls. Each sample was run in duplicate in separate wells of the 384-well real-time PCR plate. The DNA samples were subjected to real-time PCR using a 7900HT Fast Real-Time PCR System (Applied Biosystems).

Temperature cycling was as described by Moya et al. (2009) with some variations. Specific conditions were as follows: stage $1: 50^{\circ} \mathrm{C}$ for $2 \mathrm{~min}$; stage $2: 95^{\circ} \mathrm{C}$ for $10 \mathrm{~min}$; stage 3: 45 cycles alternating denaturation at $95^{\circ} \mathrm{C}$ for $15 \mathrm{~s}$, then annealing and polymerization at $60^{\circ} \mathrm{C}$ for $1 \mathrm{~min}$. Results from real-time PCR were used to estimate BCP according to calculations described by Castillo-Lopez et al. (2010). Calculation of bacterial N was based on the ratio bacterial DNA marker:N from lyophilized bacterial samples and the DNA marker in the rumen bag residues. Similar to the purine assay, bacterial $\mathrm{N}$ was multiplied times 6.25 to obtain $\mathrm{BCP}$.

\section{In Vitro Procedure to Estimate Ruminal Degradation of Protein}

The in vitro ammonia release procedure (Britton et al., 1978; Corrigan et al., 2009) was also used to estimate ruminal degradation of protein across feedstuffs. Ruminal contents were collected from the 2 cows used in the in situ and mobile bag techniques and then squeezed through 4 layers of cheesecloth and the filtrate was retained. In the laboratory, equal volumes of the filtrate and cold buffer (McDougall, 1948) were mixed, and 30 $\mathrm{mL}$ of this inoculum was pipetted into $50-\mathrm{mL}$ plastic centrifuge tubes containing the samples. The amount of sample in each tube was determined so that each tube contained $20 \mathrm{mg}$ of $\mathrm{N}$. Tubes were flushed with $\mathrm{CO}_{2}$, capped with gas-release rubber stoppers, and incubated in a water bath at $39^{\circ} \mathrm{C}$ for 18 or $24 \mathrm{~h}$. After incubation, fermentation in the tubes was stopped by adding $2 \mathrm{~mL}$ of $3 \mathrm{~N} \mathrm{HCl}$ and tubes were subsequently chilled in an ice bath. Tubes were then centrifuged at $7,000 \times g$ for $10 \mathrm{~min}$ at room temperature, and the supernatant was analyzed for $\mathrm{NH}_{3}$ concentration by spectrophotometry (Spectramax 250, Molecular Devices Corp., Sunnyvale, CA) according to the method of Broderick and Kang (1980) and for VFA concentrations by chromatography (Trace 1300 gas chromatograph, Thermo Scientific, Waltham, MA) according to the method of Erwin et al. (1961).

Concentrations of $\mathrm{NH}_{3}$ and total VFA were adjusted for a blank (inoculum only) at each incubation time. Soybean meal and SBM plus $0.1 \mathrm{~g}$ of Solka-Floc (International Fiber Corp., North Tonawanda, NY) were used as standards. Based on the assumption that an increase in the total VFA concentration represented an increase of microbial synthesis, then using the values of $\mathrm{NH}_{3}$ and total VFA concentrations from SBM and SBM plus Solka-Floc allowed us to calculate a correction factor to adjust the $\mathrm{NH}_{3}$ concentrations in the tubes across feedstuffs and RUP was calculated as follows: [(initial $\mathrm{N}$ in the tube $-\mathrm{NH}_{3}-\mathrm{N}$ in the tube)/initial $\mathrm{N}$ in the tube] $\times 100$.

\section{Statistical Analysis}

Data for rumen degradation and intestinal digestibilities of CP and AA, AA profile of the RUP after $16 \mathrm{~h}$ in situ incubation, and AA concentration in the 
Table 1. Chemical composition (\% of DM, unless otherwise noted) of feedstuffs $(n=5)$

\begin{tabular}{|c|c|c|c|c|c|c|c|c|c|c|c|c|c|c|}
\hline Item & \multicolumn{14}{|c|}{ Feedstuff $^{1}$} \\
\hline DM ( $\%$ as fed) & 94.4 & 0.30 & 86.7 & 0.85 & 87.0 & 1.66 & 90.7 & 0.40 & 89.2 & 1.52 & 88.6 & 0.33 & 88.9 & 0.43 \\
\hline $\mathrm{CP}$ & 96.1 & 1.27 & 96.3 & 0.51 & 97.6 & 0.46 & 40.7 & 0.11 & 31.4 & 0.90 & 51.5 & 0.68 & 46.4 & 0.65 \\
\hline $\mathrm{ADF}$ & 0.42 & 0.04 & 0.40 & 0.07 & 0.38 & 0.04 & 18.5 & 0.76 & 10.5 & 1.49 & 4.12 & 0.41 & 8.34 & 0.80 \\
\hline Sugar & 0.50 & 0.34 & 0.74 & 0.55 & 0.28 & 0.18 & 10.4 & 0.55 & 3.26 & 0.92 & 15.2 & 0.72 & 13.4 & 0.83 \\
\hline Crude fat & 0.33 & 0.22 & 0.69 & 0.05 & 0.43 & 0.12 & 4.21 & 0.31 & 6.11 & 0.20 & 1.29 & 0.26 & 6.48 & 0.47 \\
\hline $\mathrm{NFC}^{2}$ & 0.47 & 0.41 & 0.44 & 0.55 & 0.09 & 0.25 & 18.0 & 2.28 & 25.0 & 0.91 & 32.9 & 0.50 & 22.1 & 1.88 \\
\hline Ash & 2.44 & 0.61 & 1.91 & 0.27 & 1.21 & 0.25 & 8.24 & 0.73 & 5.95 & 0.73 & 6.79 & 0.20 & 6.35 & 0.23 \\
\hline $\mathrm{Ca}$ & 0.02 & $<0.01$ & 0.05 & $<0.01$ & 0.05 & 0.01 & 1.00 & 0.36 & 0.06 & 0.03 & 0.53 & 0.09 & 0.41 & 0.02 \\
\hline $\mathrm{P}$ & 0.18 & 0.09 & 0.07 & $<0.01$ & 0.07 & 0.01 & 1.12 & 0.03 & 1.04 & 0.05 & 0.78 & 0.03 & 0.76 & 0.04 \\
\hline $\mathrm{Mg}$ & 0.01 & $<0.01$ & 0.02 & $<0.01$ & 0.01 & $<0.01$ & 0.61 & 0.02 & 0.41 & 0.01 & 0.34 & 0.01 & 0.34 & 0.02 \\
\hline $\mathrm{Mn}(\mathrm{mg} / \mathrm{kg})$ & 0.20 & 0.44 & 1.20 & 0.45 & 1.00 & $<0.01$ & 70.4 & 1.82 & 17.4 & 1.34 & 40.8 & 1.79 & 36.8 & 2.17 \\
\hline $\mathrm{Zn}(\mathrm{mg} / \mathrm{kg})$ & 18.6 & 2.07 & 24.0 & 1.41 & 23.0 & 1.87 & 65.2 & 3.63 & 75.6 & 3.78 & 59.2 & 10.5 & 62.4 & 10.3 \\
\hline $\mathrm{Cu}(\mathrm{mg} / \mathrm{kg})$ & 3.00 & $<0.01$ & 7.20 & 1.10 & 6.40 & 1.14 & 5.20 & 0.45 & 3.00 & 0.71 & 17.2 & 0.84 & 16.2 & 1.10 \\
\hline
\end{tabular}

${ }^{1} \mathrm{BM} 1, \mathrm{BM} 2$, and BM3 = blood meal from source 1, source 2, and source 3, respectively; $\mathrm{CM}=$ canola meal; LFDG = low-fat distillers dried grains with solubles; SBM = soybean meal; ESBM = expeller SBM.

${ }^{2} \mathrm{NFC}=100-(\% \mathrm{NDF}+\% \mathrm{CP}+\%$ fat $+\%$ ash $)$.

RUP after $16 \mathrm{~h}$ in situ incubation to AA concentration in the original feedstuff ratios were analyzed using the MIXED procedure of SAS (SAS Institute, 2008) based on the following model:

$$
\mathrm{Y}_{\mathrm{ijk}}=\mu+\mathrm{F}_{\mathrm{i}}+\mathrm{r}_{\mathrm{j}}+\mathrm{b}_{\mathrm{k:i}}+\varepsilon_{\mathrm{ijk}},
$$

where $Y_{\mathrm{ijk}}=$ dependent variable, $\mu=$ overall mean, $F_{i}$ $=$ fixed effect of feedstuff, $r_{j}=$ random effect of replicate, $b_{k: i}=$ random effect of batch within feedstuff, and $\varepsilon_{\mathrm{ijk}}=$ residual error.

For each incubation time, in vitro data were analyzed based on the following model:

$$
\mathrm{Y}_{\mathrm{ij}}=\mu+\mathrm{F}_{\mathrm{i}}+\mathrm{b}_{\mathrm{j}: \mathrm{i}}+\varepsilon_{\mathrm{ij}},
$$

where $\mathrm{Y}_{\mathrm{ij}}=$ dependent variable, $\mu=$ overall mean, $\mathrm{F}_{\mathrm{i}}$ $=$ fixed effect of feedstuff, $b_{\mathrm{j}: \mathrm{i}}=$ random effect of batch within feedstuff, and $\varepsilon_{\mathrm{ij}}=$ residual error.

Data for $\mathrm{BCP}$ contamination were analyzed based on the following model:

$$
\mathrm{Y}_{\mathrm{ijk}}=\mu+\mathrm{F}_{\mathrm{i}}+\mathrm{r}_{\mathrm{j}}+\mathrm{b}_{\mathrm{k}: \mathrm{i}}+\mathrm{M}_{\mathrm{l}}+\mathrm{FM}_{\mathrm{il}}+\varepsilon_{\mathrm{ijkl}}
$$

where $Y_{\mathrm{ijk}}=$ dependent variable, $\mu=$ overall mean, $F_{i}$ $=$ fixed effect of feedstuff, $r_{j}=$ random effect of replicate, $b_{k: i}=$ random effect of batch within feedstuff, $\mathrm{M}_{1}$ $=$ fixed effect of method, $\mathrm{FM}_{\mathrm{il}}=$ interaction of feedstuff $\times$ method, and $\varepsilon_{\mathrm{ijkl}}=$ residual error.

\section{RESULTS AND DISCUSSION}

The chemical and AA compositions of the feedstuffs are listed in Table 1 and Table 2, respectively. In addition, the AA composition of ruminal bacteria is listed in Table 2.

Chemical composition of the blood meals from the 3 sources was similar. It should be noted that the NDF, ADF, and lignin assays were conducted on all feedstuffs, including blood meals. Although small proportions of these analytes were detected across blood meals, it is highly unlikely that these are indications of plant material contamination but more likely an artifact of the assays employed. Nonetheless, these values are reported for the sake of consistency across feedstuffs. The low fat content $(6.11 \% \mathrm{DM})$ of the LFDG reflected the partial removal of the oil by centrifugation. Overall, chemical compositions of the feedstuffs were comparable to reported values (NRC, 2001). The EAA concentration of the blood meals averaged $59.9 \% \mathrm{CP}$ and was greater than that of other feedstuffs. Generally, AA concentrations of the feedstuffs were within the ranges reported by the NRC (2001) but for LFDG, which had greater concentrations of all EAA except for Trp, which was similar. . Most notably and in agreement with others (Mjoun et al., 2010; Li et al., 2012), the Lys concentration of $3.48 \pm 0.42 \% \mathrm{CP}$ was much greater than $2.24 \pm 0.39 \%$ CP reported by the NRC (2001). Amino acid concentrations of ruminal bacteria were within the 
Table 2. Amino acid composition (\% of CP) of feedstuffs $(\mathrm{n}=5)$ and ruminal bacteria $(\mathrm{n}=2)$

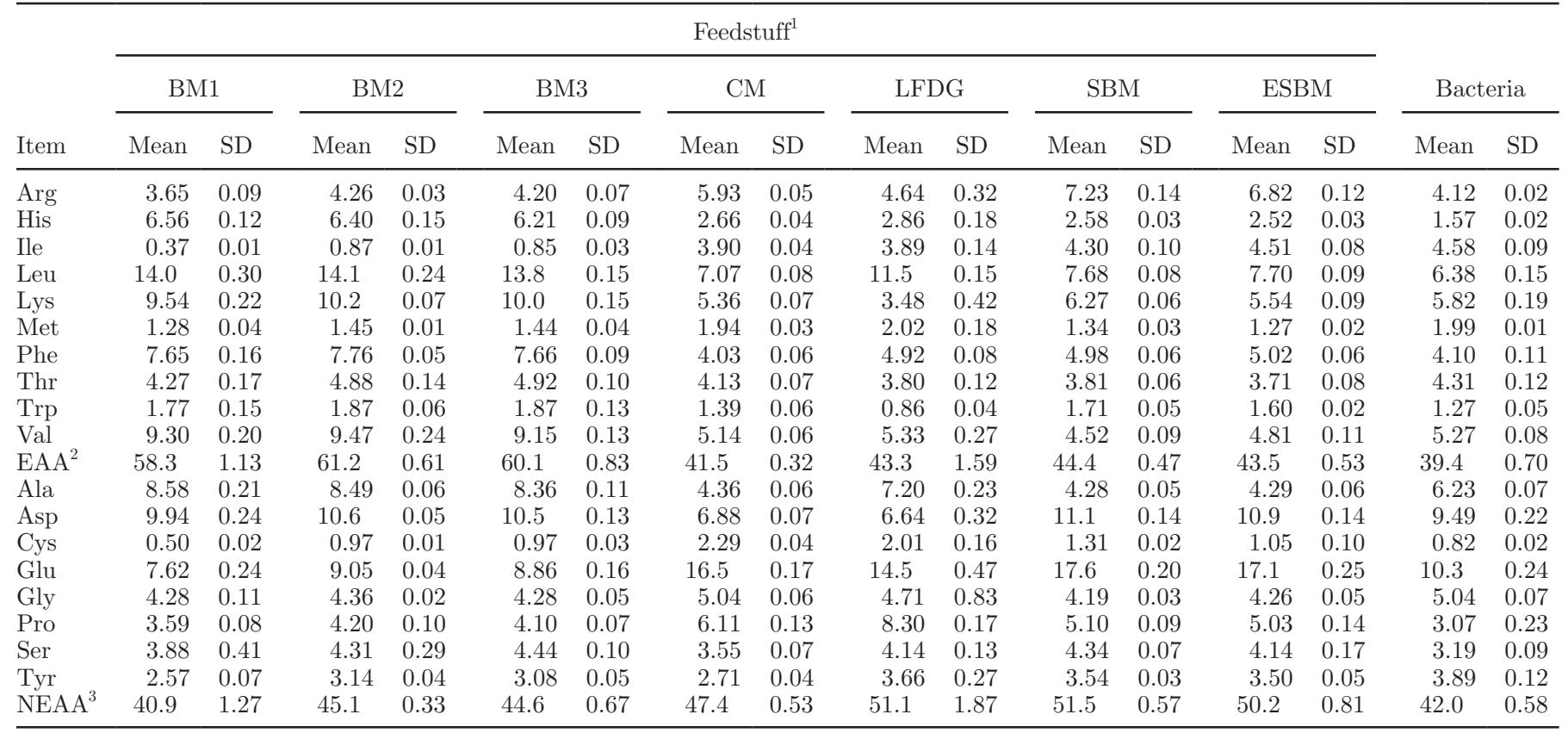

${ }^{1}$ BM1, BM2, and BM3 = blood meal from source 1, source 2, and source 3, respectively; CM = canola meal; LFDG = low-fat distillers dried grains with solubles; $\mathrm{SBM}=$ soybean meal; $\mathrm{ESBM}=$ expeller SBM.

${ }^{2} \mathrm{EAA}=$ sum of Arg, His, Ile, Leu, Lys, Met, Phe, Thr, Trp, and Val.

${ }^{3} \mathrm{NEAA}=$ sum of Ala, Asp, Cys, Glu, Gly, Pro, Ser, and Tyr.

ranges reported in the review of Clark et al. (1992). Geometric mean particle size of the ground feedstuffs (Table 3) were $0.40,0.22 .0 .21,0.35,0.38,0.65$, and $0.49 \pm 0.03 \mathrm{~mm}$ for BM1, BM2, BM3, CM, LFDG, SBM, and ESBM, respectively.

\section{Ruminal Degradation of $D M, C P$, and $A A$}

Ruminal degradation of DM, CP, and AA after $16 \mathrm{~h}$ in situ incubation is listed in Table 4. Ruminal degradation of DM varied greatly $(P<0.01)$ within blood meal sources, with a difference of 60.9 percentage units between BM1 and BM2. For the remaining feedstuffs, ruminal degradation of DM ranged between 57.2 and $78.9 \pm 3.18 \%$. Ruminal degradation of CP was similar for BM2 and greater for BM1 and BM3 compared with reported values (NRC, 2001). Howie et al. (1996) observed large variation in ruminal degradation between and within 2 types of blood meals, which was believed to be the result of inconsistencies in the processing methods. Values of ruminal degradation of $\mathrm{CP}$ for $\mathrm{CM}$ (NRC, 2001), SBM (Mjoun et al., 2010), and ESBM (Borucki Castro et al., 2007) were consistent with those in the literature. Lower $(P<0.01)$ ruminal degradation of CP from ESBM compared with SBM has been previously reported (Borucki Castro et al., 2007) and is attributed to a reduction in the solubility of the proteins as they are denatured by exposure to heat during the processing of this product. For LFDG, ruminal degradation of $\mathrm{CP}$ was higher than is commonly observed in conventional distillers dried grains with solubles (Paz et al., 2013). In vivo data suggest that the RDP of conventional distillers grains is 37\% (Castillo-Lopez et al., 2013). Meyer et al. (2012) attributed the increase in ruminal degradation of CP in LFDG to an increase in the soluble CP fraction in the distillers solubles as fat is removed; however, in practice, removal of fat does not result in greater production of solubles; therefore, the high ruminal degradation of CP observed in this study could be related to washout of particles from the bags.

Within feedstuffs, ruminal degradation of both total EAA and NEAA followed a pattern similar to that of CP. However, variations were observed for specific AA. Across BM sources, Trp was the most degraded, whereas Ile and Ser were the least degraded. Similar to the observations of Maxin et al. (2013) for CM, His was among the most degraded AA, whereas Tyr was among the least. For LFDG, His and Lys were the most degraded AA, which is consistent with Mjoun et al. (2010), whereas Glu and Leu were the least degraded. Arginine and Trp were the most degraded AA for SBM and ESBM, respectively, whereas Met and the branched-chain AA were the least degraded. These observations are in agreement with those of others (Borucki Castro et al., 2007; Maxin et al., 2013). Differences in ruminal degradation of AA within a feedstuff 
Table 3. Particle size distribution of the feedstuffs

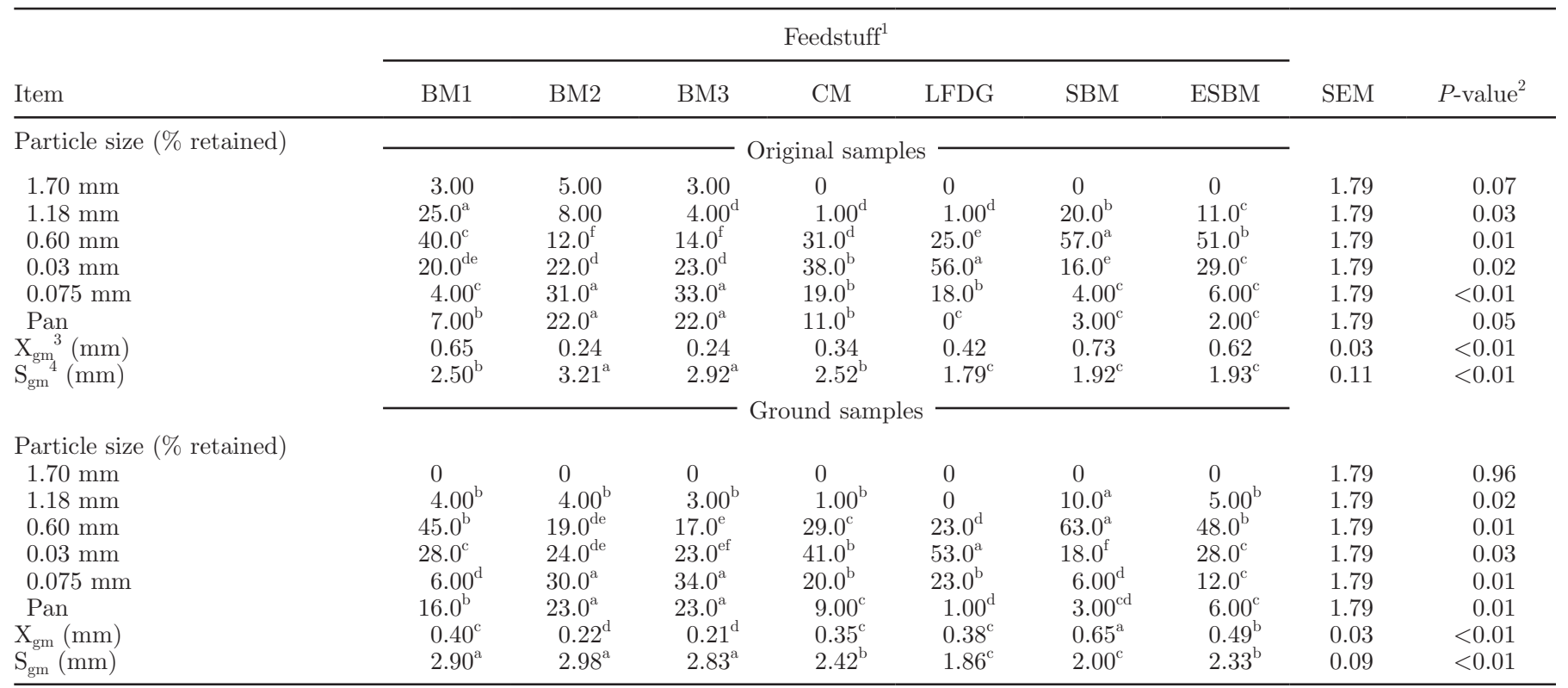

${ }^{\mathrm{a}-\mathrm{f}}$ Means within a row with different superscripts differ $(P \leq 0.05)$.

${ }^{1} \mathrm{BM} 1, \mathrm{BM} 2$, and BM3 = blood meal from source 1, source 2, and source 3, respectively; CM = canola meal; LFDG = low-fat distillers dried grains with solubles; SBM = soybean meal; ESBM = expeller SBM.

${ }^{2}$ For particle size, $P$-value from treatment (feedstuff) $\times$ screen effect; for $\mathrm{X}_{\mathrm{gm}}$ and $\mathrm{S}_{\mathrm{gm}}, P$-value from treatment effect (feedstuff).

${ }^{3}$ Geometric mean determined by American Society of Agricultural and Biological Engineers (ASABE, 2008) guidelines.

${ }^{4}$ Geometric standard deviation determined by ASABE guidelines.

Table 4. Ruminal degradation (\%) of DM, CP, and AA after $16 \mathrm{~h}$ in situ incubation

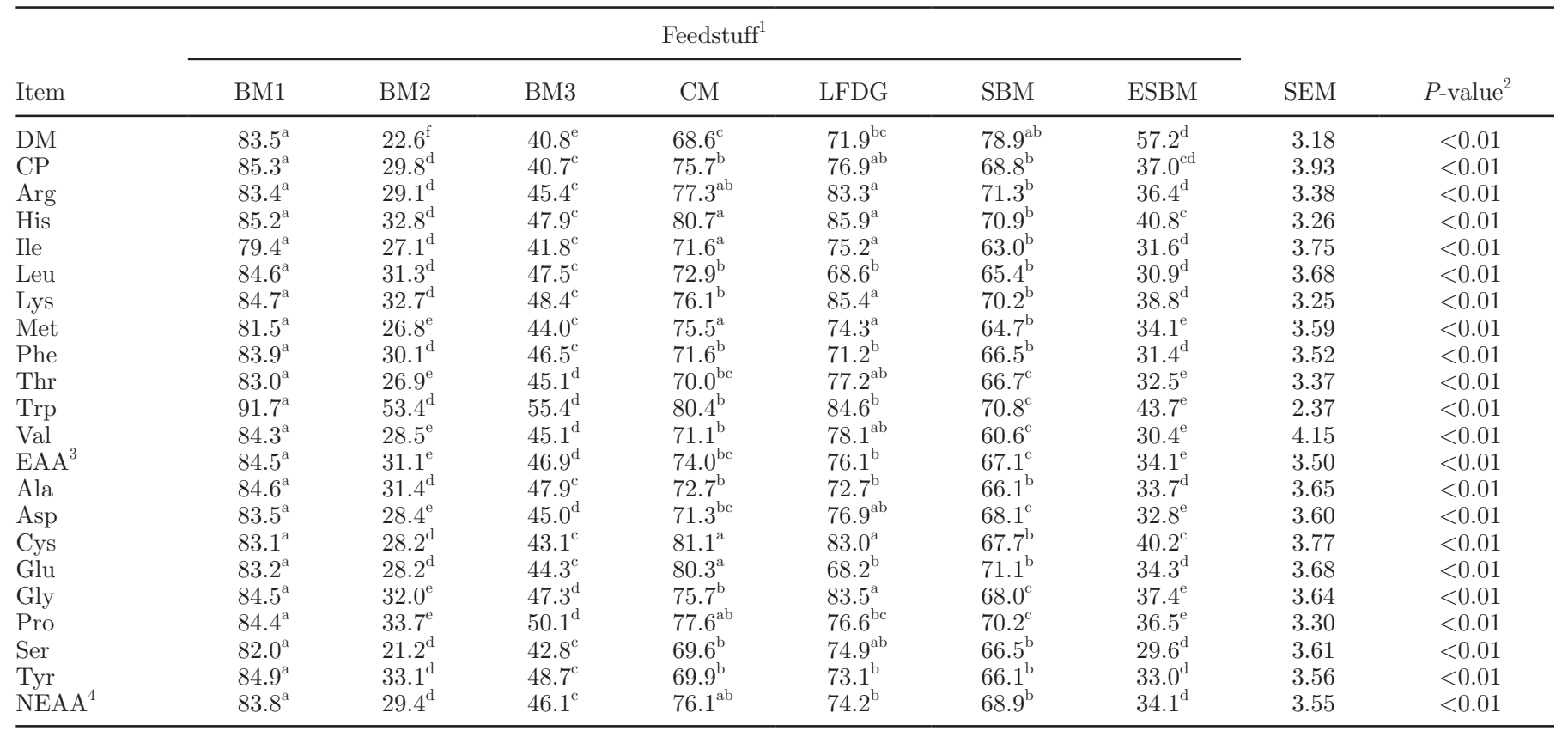

${ }^{\mathrm{a}-\mathrm{f}}$ Means within a row with different superscripts differ $(P<0.01)$.

${ }^{1} \mathrm{BM} 1, \mathrm{BM}$, and BM3 = blood meal from source 1, source 2, and source 3, respectively; CM = canola meal; LFDG = low-fat distillers dried grains with solubles; $\mathrm{SBM}=$ soybean meal; ESBM = expeller SBM.

${ }^{2}$ Treatment effect (feedstuff).

${ }^{3} \mathrm{EAA}=$ sum of Arg, His, Ile, Leu, Lys, Met, Phe, Thr, Trp, and Val.

${ }^{4} \mathrm{NEAA}=$ sum of Ala, Asp, Cys, Glu, Gly, Pro, Ser, and Tyr. 
may be influenced by protein composition and their variable inherent characteristics such as structure and AA profile (Messman and Weiss, 1994; van Straalen et al., 1997) and also by processing (Yoon et al., 1996).

\section{RUP and AA Profile of RUP}

Rumen-undegradable protein and AA profile of RUP after $16 \mathrm{~h}$ in situ incubation, and ratios of AA concentration in the RUP after $16 \mathrm{~h}$ in situ incubation to AA concentration in the original feedstuffs are listed in Table 5. Across feedstuffs, the 16-h incubation time point was chosen to simulate retention time; this time point is commonly used throughout studies (Boucher et al., 2009), allowing for accurate comparisons across studies. In addition, assuming that in situ incubation closely mimics in vivo rumen conditions, the residue remaining after $16 \mathrm{~h}$ in situ incubation should have similar digestibility to RUP. This procedure may be an oversimplification of estimating RUP because escape of protein from rumen degradation is complex and affected by many factors, including the rate of degradation in the rumen and other chemical and physical factors of the feedstuff (NRC, 2001). Across feedstuffs, correction for BCP contamination using purines or DNA as bacterial marker resulted in similar ranking of the RUP values. In addition, correction for $\mathrm{BCP}$ contamination did not change ranking of the RUP values compared with uncorrected values. For absolute values of RUP, correcting for $\mathrm{BCP}$ contamination had considerable effects on CM, LFDG, and ESBM (Figure 1). Estimations of BCP contamination using purines or DNA as bacterial marker were similar for BM1, BM2, BM3, and SBM and averaged 0.71, 0.41, 0.59, and 1.98\%, respectively. Compared with purines, estimates of $\mathrm{BCP}$ contamination using DNA as bacterial marker were lower for LFDG $(P<0.01)$ and ESBM $(P<0.01)$ and higher $(P=0.05)$ for CM. After ruminal incubation and washing of the rumen bags, purines from the feedstuff residue can originate from bacterial and protozoan contamination, thus representing microbial contamination, and also from the feedstuff residue itself. Because the genetic marker only targeted bacteria, lower values may be related to the estimation of $\mathrm{BCP}$ contamination rather than microbial contamination. On the other hand, in the case of $\mathrm{CM}$, the reason for overestimation of BCP contamination is not apparent. The presence of multiple copy numbers of the DNA marker may lead to overestimation of BCP and is a source of variation of the method (Kang et al., 2010). Estimations of BCP contamination were linearly correlated with NDF concentration of the feedstuff when using DNA $(P<$ $0.01 ; \mathrm{r}=0.90)$ but not when using purines as bacterial marker $(P=0.15$; Figure 2$)$.
The in vitro procedure was also used to estimate RUP across feedstuffs. This method is not subject to errors that may emerge with washout of feedstuff particles (Corrigan et al., 2009) and allows for a more controlled and uniform setting. Compared with the RUP values estimated from the mobile bag technique, marked differences were observed for the RUP mean values of BM1, BM3, CM, and LFDG estimated using the in vitro procedure. Additionally, within feedstuffs batches, wide variation was observed (CV ranged from 8.85 to $46.0 \%$ ). Similar to the mobile bag technique, the in vitro procedure might not be adequate for all feedstuffs and more research is needed to elucidate the factors that cause variation in the estimation of $\mathrm{CP}$ degradation when using this procedure.

The ratios of AA concentration in the RUP after $16 \mathrm{~h}$ in situ incubation to AA concentration in the original feedstuff (Maxin et al., 2013) were used to evaluate whether the AA profile of the RUP differs from that of the original feedstuff. A ratio $<1$ reflects a decrease whereas a ratio $>1$ reflects an increase in the concentration of a specific AA in the RUP relative to the original concentration of the specific AA in the feedstuff protein. In general, ruminal incubation decreased $(P<0.01)$ the concentrations of His, Lys, and Trp, and increased $(P>0.001)$ the concentrations of Ile and Met across feedstuffs. For NEAA, changes were variable across feedstuffs. The previous results are consistent with ruminal degradation of AA and are in agreement with others (Kelzer et al., 2010; Maxin et al., 2013). Overall, ruminal degradation modifies the AA profile from feedstuffs before reaching the small intestine. The AA profile of RUP after $16 \mathrm{~h}$ of in situ incubation corrected for BCP contamination is listed in Table 6. Overall, rankings of AA across feedstuffs were similar to uncorrected values using either method.

\section{Intestinal Digestibility of RUP and AA in RUP and Intestinal Absorbable AA}

Intestinal digestibility of RUP and AA in the RUP and total-tract digestibility of DM and $\mathrm{CP}$ are listed in Table 7. Across feedstuffs, total-tract digestibility of DM was lowest $(P<0.01)$ for CM and LFDG, at 80.3 and $81.4 \%$, respectively. High $(>98 \%)$ total-tract digestibility of DM for BM1, BM3, and SBM did not allow for enough residue to be recovered for $\mathrm{CP}$ and AA analyses, thus total-tract digestibility of $\mathrm{CP}$ and intestinal digestibility of RUP and AA in RUP for these feedstuffs could not be determined. In the case of ESBM, enough residue was recovered to estimate intestinal digestibility of RUP but not for specific AA in RUP. Intestinal digestibility of RUP was highest $(P<$ 0.01) for ESBM, followed by BM2 and LFDG, and was 
Table 5. Rumen-undegradable protein, AA profile of RDP after $16 \mathrm{~h}$ in situ incubation, and ratios of AA concentration in the RUP after $16 \mathrm{~h}$ in situ incubation to AA concentration in the original feedstuff

\begin{tabular}{|c|c|c|c|c|c|c|c|c|c|}
\hline \multirow[b]{2}{*}{ Item } & \multicolumn{7}{|c|}{ Feedstuff $^{1}$} & \multirow[b]{2}{*}{ SEM } & \multirow[b]{2}{*}{$P$-value ${ }^{2}$} \\
\hline & BM1 & BM2 & BM3 & $\mathrm{CM}$ & LFDG & SBM & ESBM & & \\
\hline \multicolumn{10}{|l|}{$\mathrm{RUP}^{3}(\%$ of $\mathrm{CP})$} \\
\hline Purines & $14.6^{\mathrm{d}}$ & $69.8^{\mathrm{a}}$ & $59.0^{\mathrm{b}}$ & $23.7^{\mathrm{c}}$ & $21.6^{\mathrm{cd}}$ & $30.3^{\mathrm{c}}$ & $56.2^{\mathrm{b}}$ & 3.86 & $<0.01$ \\
\hline DNA & $14.6^{\mathrm{d}}$ & $70.1^{\mathrm{a}}$ & $58.9^{\mathrm{b}}$ & $23.2^{\text {cd }}$ & $22.5^{\mathrm{cd}}$ & $30.7^{\mathrm{c}}$ & $61.4^{\mathrm{ab}}$ & 3.88 & $<0.01$ \\
\hline In vitro, $18 \mathrm{~h}$ & $29.5^{\mathrm{c}}$ & $65.5^{\mathrm{a}}$ & $58.8^{\mathrm{ab}}$ & $27.1^{\mathrm{c}}$ & $50.6^{\mathrm{b}}$ & $31.4^{\mathrm{c}}$ & $63.7^{\mathrm{a}}$ & 4.56 & $<0.01$ \\
\hline \multicolumn{10}{|c|}{ AA ( $\%$ of RUP and ratios) } \\
\hline Arg & $3.87^{\mathrm{e}}$ & $4.07^{\mathrm{d}}$ & $4.10^{\mathrm{d}}$ & $5.91^{\mathrm{c}}$ & $3.24^{\mathrm{f}}$ & $6.75^{\mathrm{b}}$ & $6.99^{\mathrm{a}}$ & 0.03 & $<0.01$ \\
\hline Ratio & $1.06^{\mathrm{a} *}$ & $0.96^{\mathrm{ed} *}$ & $0.98^{\mathrm{cd} *}$ & $1.00^{\mathrm{cb}}$ & $0.70^{\mathrm{f}} *$ & $0.93^{\mathrm{e} *}$ & $1.03^{\mathrm{b} *}$ & 0.01 & $<0.01$ \\
\hline His & $6.39^{\mathrm{a}}$ & $6.02^{\mathrm{b}}$ & $6.03^{\mathrm{b}}$ & $2.12^{\mathrm{e}}$ & $1.74^{\mathrm{f}}$ & $2.53^{\mathrm{c}}$ & $2.43^{\mathrm{d}}$ & 0.04 & $<0.01$ \\
\hline Ratio & $0.98^{\mathrm{ab}}$ & $0.94^{\mathrm{b} *}$ & $0.97^{\mathrm{ab} *}$ & $0.80^{\mathrm{c} *}$ & $0.61^{\mathrm{d} *}$ & $0.98^{\mathrm{a}}$ & $0.96^{\mathrm{ab} *}$ & 0.01 & $<0.01$ \\
\hline Ile & $0.48^{\mathrm{f}}$ & $0.86^{\mathrm{e}}$ & $0.88^{\mathrm{e}}$ & $4.89^{\mathrm{c}}$ & $4.08^{\mathrm{d}}$ & $5.18^{\mathrm{a}}$ & $4.98^{\mathrm{b}}$ & 0.03 & $<0.01$ \\
\hline Ratio & $1.31^{\mathrm{a} *}$ & $0.98^{\mathrm{f}}$ & $1.04^{\mathrm{e} *}$ & $1.25^{\mathrm{b} *}$ & $1.05^{\mathrm{e} *}$ & $1.21^{\mathrm{c} *}$ & $1.10^{\mathrm{d} *}$ & 0.01 & $<0.01$ \\
\hline Ratio & $1.18^{\mathrm{a} *}$ & $0.99^{\mathrm{c}}$ & $1.00^{\mathrm{c}}$ & $1.08^{\mathrm{b} *}$ & $1.08^{\mathrm{b} *}$ & $1.15^{\mathrm{a} *}$ & $1.06^{\mathrm{b} *}$ & 0.02 & $<0.01$ \\
\hline Phe & $7.87^{\mathrm{a}}$ & $7.33^{\mathrm{b}}$ & $7.33^{\mathrm{b}}$ & $5.06^{\mathrm{f}}$ & $6.00^{\mathrm{c}}$ & $5.43^{\mathrm{e}}$ & $5.55^{\mathrm{d}}$ & 0.03 & $<0.01$ \\
\hline Ratio & $1.03^{\mathrm{d} *}$ & $0.94^{\mathrm{e} *}$ & $0.96^{\mathrm{e} *}$ & $1.25^{\mathrm{a} *}$ & $1.22^{\mathrm{b} *}$ & $1.09^{\mathrm{c} *}$ & $1.11^{\mathrm{c} *}$ & 0.01 & $<0.01$ \\
\hline Thr & $4.61^{\mathrm{c}}$ & $4.82^{\mathrm{b}}$ & $4.83^{\mathrm{b}}$ & $5.51^{\mathrm{a}}$ & $3.67^{\mathrm{f}}$ & $4.13^{\mathrm{d}}$ & $4.04^{\mathrm{e}}$ & 0.05 & $<0.01$ \\
\hline Ratio & $1.08^{\mathrm{b} *}$ & $0.99^{\mathrm{c}}$ & $0.98^{\mathrm{c}}$ & $1.34^{\mathrm{a} *}$ & $0.97^{\mathrm{c}}$ & $1.08^{\mathrm{b} *}$ & $1.09^{\mathrm{b} *}$ & 0.02 & $<0.01$ \\
\hline Trp & $0.93^{\mathrm{d}}$ & $1.18^{\mathrm{c}}$ & $1.50^{\mathrm{b}}$ & $1.19^{\mathrm{c}}$ & $0.56^{\mathrm{e}}$ & $1.63^{\mathrm{a}}$ & $1.45^{\mathrm{b}}$ & 0.04 & $<0.01$ \\
\hline Ratio & $0.53^{\mathrm{e} *}$ & $0.63^{\mathrm{d} *}$ & $0.81^{\mathrm{c} *}$ & $0.86^{\mathrm{bc} *}$ & $0.66^{\mathrm{d} *}$ & $0.96^{\mathrm{a}}$ & $0.91^{\mathrm{ab} *}$ & 0.02 & $<0.01$ \\
\hline Val & $9.28^{\mathrm{a}}$ & $9.13^{\mathrm{b}}$ & $8.96^{\mathrm{c}}$ & $6.58^{\mathrm{d}}$ & $4.92^{\mathrm{g}}$ & $5.79^{\mathrm{e}}$ & $5.38^{\mathrm{f}}$ & 0.08 & $<0.01$ \\
\hline Ratio & $1.00^{\mathrm{c}}$ & $0.96^{\text {cd }}$ & $0.98^{\mathrm{c}}$ & $1.28^{\mathrm{a} *}$ & $0.92^{\mathrm{d} *}$ & $1.28^{\mathrm{a} *}$ & $1.12^{\mathrm{b} *}$ & 0.02 & $<0.01$ \\
\hline $\mathrm{EAA}^{4}$ & $57.7^{\mathrm{a}}$ & $56.9^{\mathrm{b}}$ & $57.0^{\mathrm{b}}$ & $47.6^{\mathrm{c}}$ & $43.8^{\mathrm{e}}$ & $47.6^{\mathrm{c}}$ & $46.2^{\mathrm{d}}$ & 0.12 & $<0.01$ \\
\hline Ratio & $0.99^{\mathrm{c}}$ & $0.93^{\mathrm{d} *}$ & $0.95^{\mathrm{d} *}$ & $1.14^{\mathrm{a} *}$ & $1.01^{\mathrm{c}}$ & $1.07^{\mathrm{b} *}$ & $1.06^{\mathrm{b} *}$ & 0.01 & $<0.01$ \\
\hline Ala & $8.44^{\mathrm{a}}$ & $7.85^{\mathrm{c}}$ & $7.79^{\mathrm{d}}$ & $5.26^{\mathrm{e}}$ & $8.29^{\mathrm{b}}$ & $4.74^{\mathrm{f}}$ & $4.59^{\mathrm{g}}$ & 0.03 & $<0.01$ \\
\hline Ratio & $0.98^{\mathrm{e}}$ & $0.93^{\mathrm{f} *}$ & $0.93^{\mathrm{f} *}$ & $1.21^{\mathrm{a} *}$ & $1.15^{\mathrm{b} *}$ & $1.11^{\mathrm{c} *}$ & $1.07^{\mathrm{d} *}$ & 0.01 & $<0.01$ \\
\hline Asp & $10.5^{\mathrm{c}}$ & $10.3^{\mathrm{d}}$ & $10.3^{\mathrm{d}}$ & $8.73^{\mathrm{e}}$ & $6.46^{\mathrm{f}}$ & $11.6^{\mathrm{b}}$ & $11.8^{\mathrm{a}}$ & 0.03 & $<0.01$ \\
\hline Ser & $4.40^{\mathrm{d}}$ & $4.58^{\mathrm{bc}}$ & $4.54^{\mathrm{cd}}$ & $4.78^{\mathrm{a}}$ & $4.39^{\mathrm{d}}$ & $4.72^{\mathrm{ab}}$ & $4.71^{\mathrm{ab}}$ & 0.07 & $<0.01$ \\
\hline Ratio & $1.14^{\mathrm{b} *}$ & $1.07^{\mathrm{bc}}$ & $1.02^{\mathrm{c}}$ & $1.35^{\mathrm{a} *}$ & $1.06^{\mathrm{bc}}$ & $1.09^{\mathrm{bc} *}$ & $1.14^{\mathrm{b} *}$ & 0.03 & $<0.01$ \\
\hline Tyr & $2.47^{\mathrm{f}}$ & $2.84^{\mathrm{e}}$ & $2.83^{\mathrm{e}}$ & $3.61^{\mathrm{d}}$ & $4.13^{\mathrm{a}}$ & $3.92^{\mathrm{b}}$ & $3.78^{\mathrm{c}}$ & 0.02 & $<0.01$ \\
\hline Ratio & $0.96^{\mathrm{d} *}$ & $0.90^{\mathrm{e} *}$ & $0.92^{\text {de } *}$ & $1.33^{\text {a* }}$ & $1.13^{\mathrm{b} *}$ & $1.11^{\mathrm{bc} *}$ & $1.08^{\mathrm{c} *}$ & 0.02 & $<0.01$ \\
\hline $\mathrm{NEAA}^{5}$ & $42.2^{\mathrm{f}}$ & $43.0^{\mathrm{e}}$ & $42.9^{\mathrm{e}}$ & $49.9^{\mathrm{d}}$ & $55.5^{\mathrm{a}}$ & $52.2^{\mathrm{c}}$ & $53.4^{\mathrm{b}}$ & 0.12 & $<0.01$ \\
\hline Ratio & $1.03^{\mathrm{cd} *}$ & $0.95^{\mathrm{e} *}$ & $0.96^{\mathrm{e} *}$ & $1.05^{\mathrm{bc} *}$ & $1.09^{\mathrm{a} *}$ & $1.01^{\mathrm{d}}$ & $1.06^{\mathrm{ab} *}$ & 0.01 & $<0.01$ \\
\hline
\end{tabular}

${ }^{\mathrm{a}-\mathrm{g}}$ Means within a row with different superscript differ $(P<0.01)$.

${ }^{1} \mathrm{BM} 1, \mathrm{BM} 2$, and BM3 = blood meal from source 1, source 2, and source 3, respectively; $\mathrm{CM}=$ canola meal; LFDG = low-fat distillers dried grains with solubles; $\mathrm{SBM}=$ soybean meal; ESBM = expeller SBM.

${ }^{2}$ Treatment effect (feedstuff).

${ }^{3} \mathrm{In}$ situ = RUP uncorrected for bacterial CP (BCP) contamination; purines $=$ RUP corrected for BCP contamination using purines as a bacterial marker; DNA = RUP corrected for BCP contamination using DNA as a bacterial marker; in vitro $18 \mathrm{~h}, 24 \mathrm{~h}$, or mean $=$ RUP from in vitro procedure at $18 \mathrm{~h}, 24 \mathrm{~h}$, or the mean of 18 and $24 \mathrm{~h}$, respectively.

${ }^{4} \mathrm{EAA}=$ sum of Arg, His, Ile, Leu, Lys, Met, Phe, Thr, Trp, and Val.

${ }^{5} \mathrm{NEAA}=$ sum of Ala, Asp, Cys, Glu, Gly, Pro, Ser, and Tyr.

*Indicates that the ratio is different from $1(P \leq 0.05)$. 


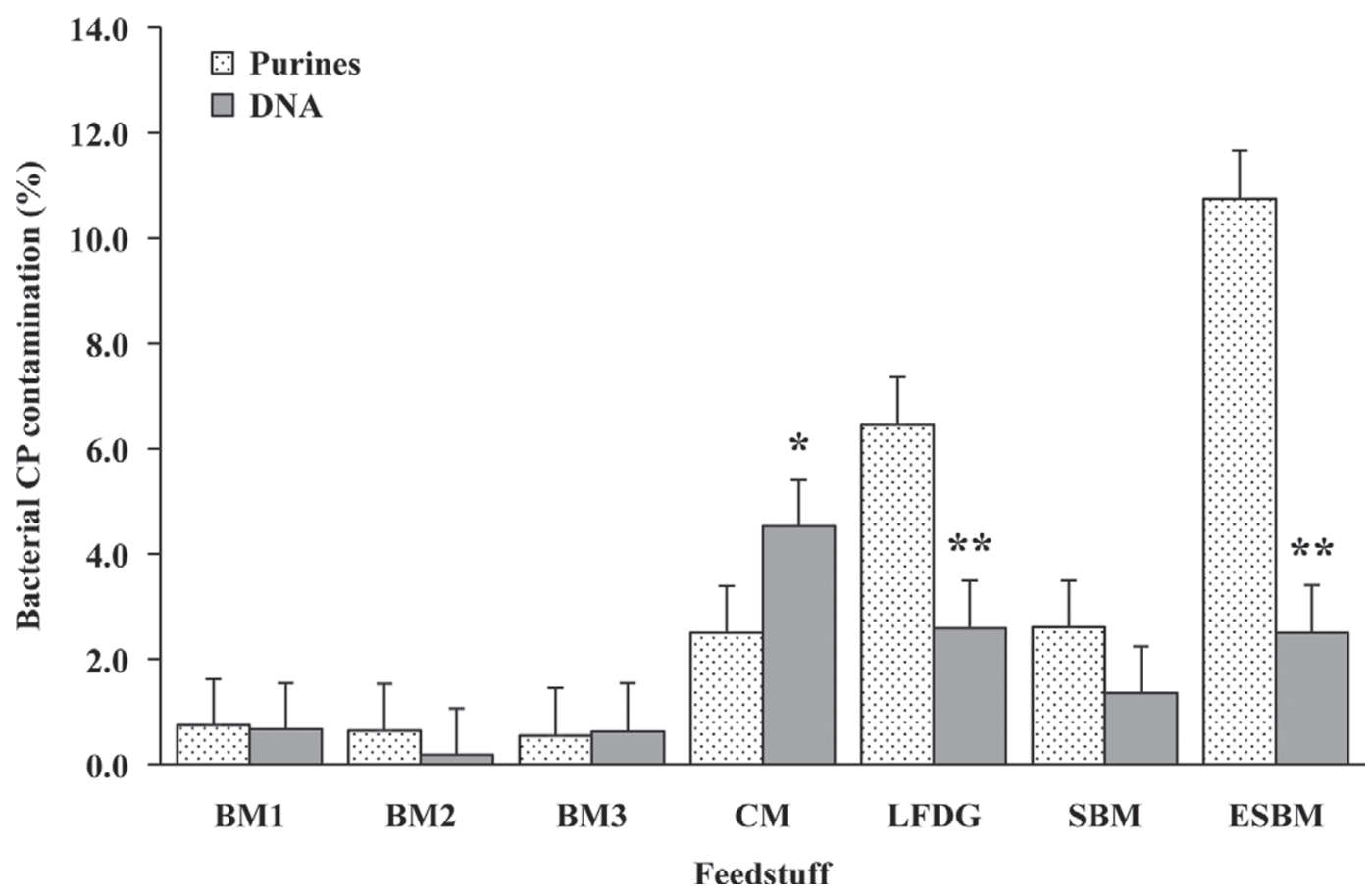

Figure 1. Bacterial CP contamination determined by the use of purines or DNA as bacterial markers. BM1, BM2, and BM3 = blood meal from source 1, source 2, and source 3, respectively; $\mathrm{CM}=$ canola meal; LFDG $=$ low-fat distillers dried grains with solubles; $\mathrm{SBM}=$ soybean meal; ESBM $=$ expeller SBM. Values shown are mean \pm SEM. Within feedstuff, ${ }^{*} P=0.05$ and ${ }^{* *} P<0.01$ different from purines as bacterial marker. Interaction feedstuff $\times$ method $=P<0.01$.

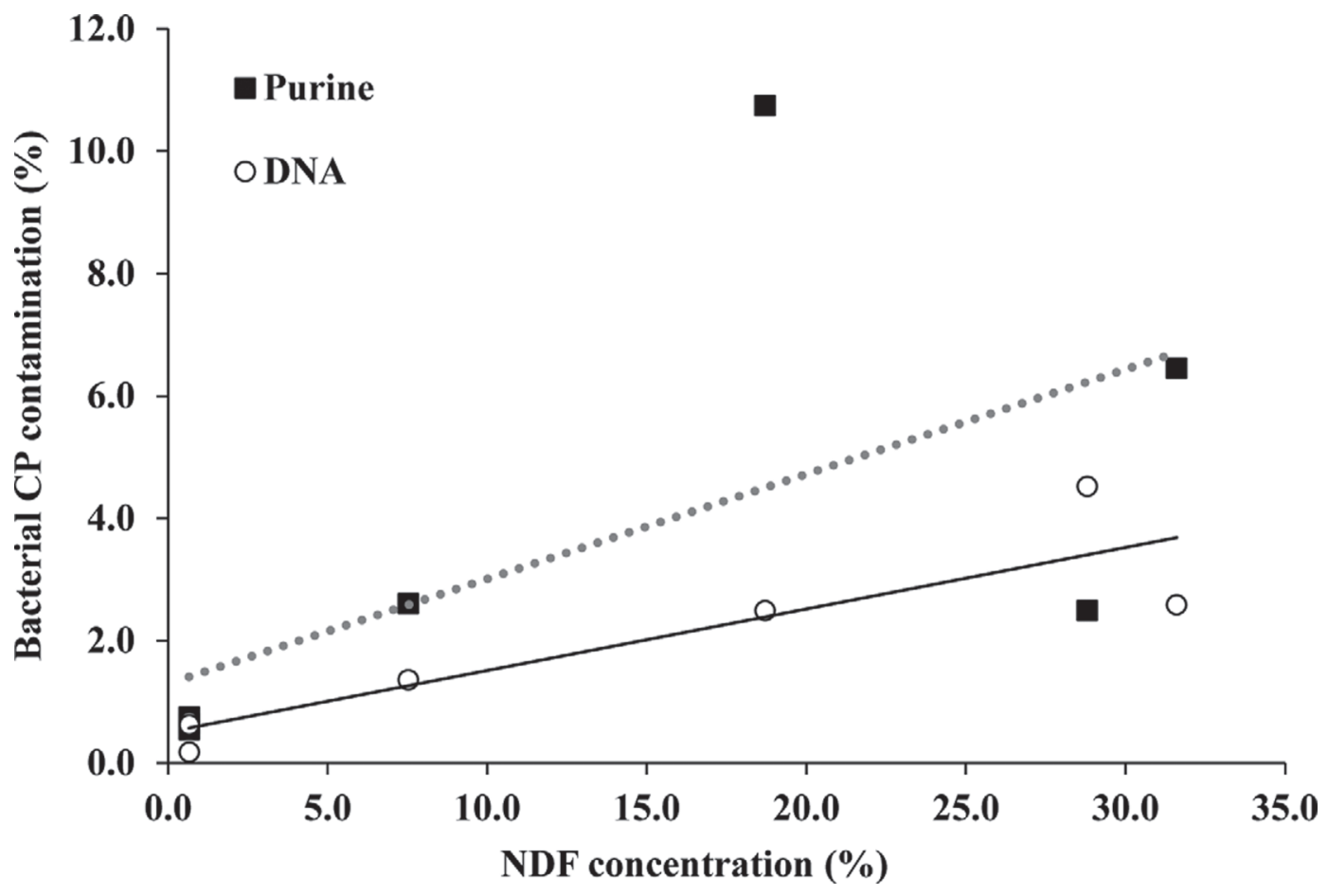

Figure 2. Relationships between bacterial CP contamination determined by purines $(P=0.15)$ or DNA $\left(\mathrm{y}=0.50+0.10 \mathrm{x} ; P<0.01 ; \mathrm{R}^{2}=\right.$ 0.81 ) as bacterial marker and NDF concentration of the feedstuff. 


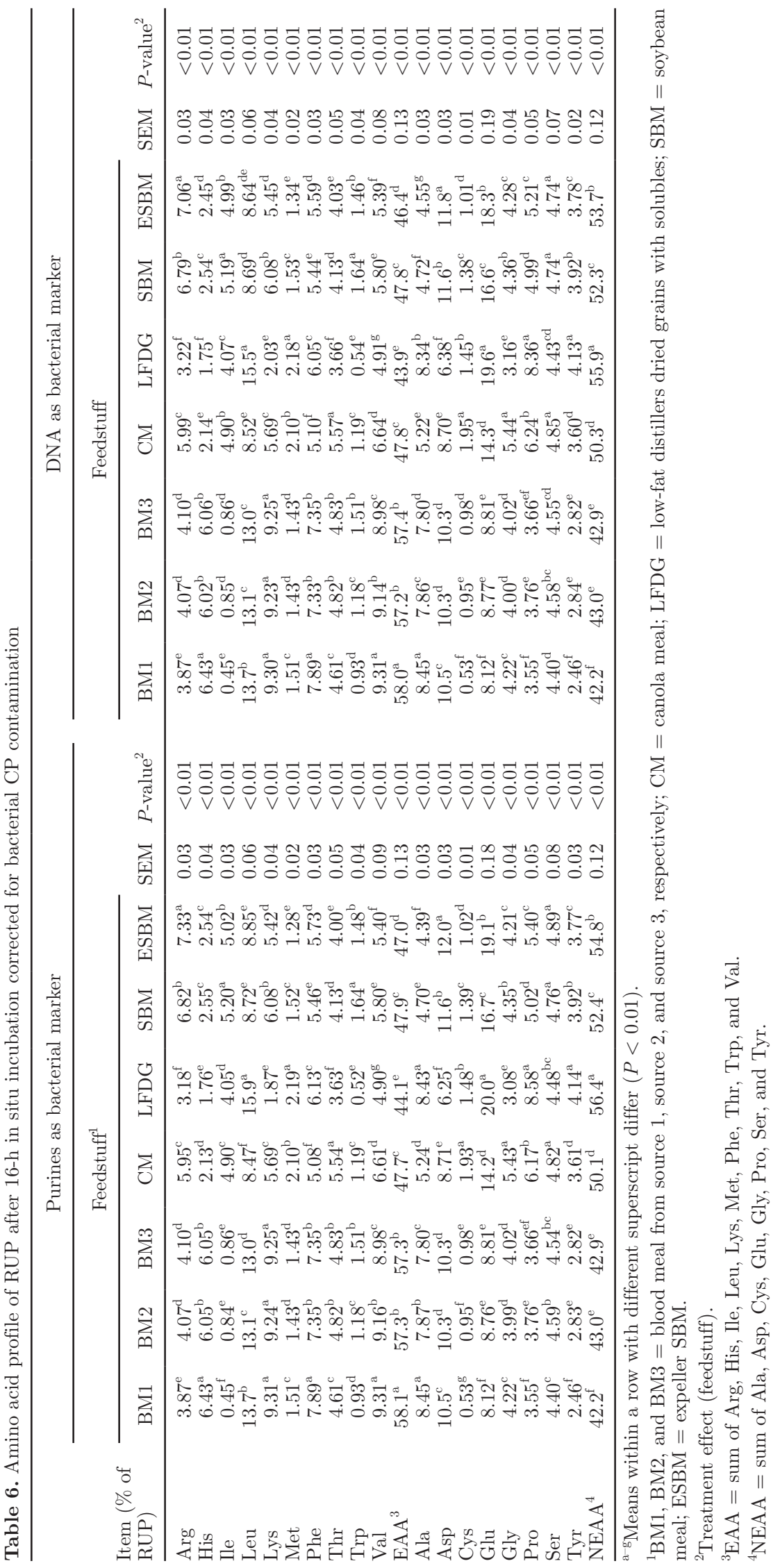


lowest for CM. Observations for LFDG (Kelzer et al., 2010) and ESBM (Borucki Castro et al., 2007) agree with published values. Using the mobile bag technique, Erasmus et al. (1994) reported that the intestinal digestibility of RUP of blood meal was $56.3 \%$, which is lower than the $87.9 \%$ observed for BM2 in this study, whereas Harstad and Prestlokken (2001) reported that the intestinal digestibility of RUP of CM was $94.6 \%$, which is higher than the $72.4 \%$ observed in this study. Intestinal digestibilities of total EAA and NEAA were high $(>88 \% ; P<0.01)$ across feedstuffs. Overall, totaltract digestibility of $\mathrm{CP}$ was high $(>91 \% ; P<0.01)$ across feedstuffs.

Intestinal absorbable AA supplied by the RUP and intestinal absorbable dietary protein are listed in Table 8. Intestinal absorbable dietary protein and, more specifically, its constituent AA represent the $\mathrm{N}$ sources coming from the feedstuff that will be available for absorption by the cow for the synthesis of milk proteins; it is calculated as RUP times its intestinal digestibility. Intestinal absorbable dietary protein was higher $(P<$ 0.01) for BM2 compared with CM and LFDG: 61.7, 17.9 , and $20.7 \pm 2.73 \% \mathrm{CP}$, respectively. Intestinal ab- sorbable EAA and NEAA followed the same pattern as intestinal absorbable dietary protein. Differences were observed in the profile of intestinal absorbable AA supplied across feedstuffs, which emphasizes the importance of models to account for this factor to improve the accuracy of estimating the dietary supply of AA. In the present study, we observed marked variation in protein quality across blood meals. Based on the total-tract digestibilities (>98\%) of BM1 and BM3, it is safe to assume $100 \%$ intestinal digestibility of RUP and AA in RUP in these feedstuffs. Thus, the amount of intestinal absorbable Lys provided by $0.5 \mathrm{~kg}$ of BM1, BM2, and BM3 will be 7, 29, and $25 \mathrm{~g}$; respectively, and the amount of intestinal absorbable Met will be 1,5 , and $4 \mathrm{~g}$, respectively.

\section{CONCLUSIONS}

Ruminal degradation and intestinal digestibility of AA determine the supply of intestinal absorbable AA across feedstuffs. These factors are not constant across AA within feedstuffs, and models need to account for them to increase the accuracy of predicting the AA

Table 7. Intestinal digestibility of RUP and AA in RUP and total-tract digestibility of DM and $\mathrm{CP}^{1}$

\begin{tabular}{|c|c|c|c|c|c|c|c|c|c|}
\hline \multirow[b]{2}{*}{ Item } & \multicolumn{7}{|c|}{ Feedstuff $^{2}$} & \multirow[b]{2}{*}{ SEM } & \multirow[b]{2}{*}{$P$-value ${ }^{3}$} \\
\hline & BM1 & BM2 & BM3 & $\mathrm{CM}$ & LFDG & SBM & ESBM & & \\
\hline \multicolumn{10}{|c|}{ Intestinal digestibility (\%) } \\
\hline RUP & & $87.9^{\mathrm{b}}$ & & $72.4^{\mathrm{c}}$ & $89.7^{\mathrm{b}}$ & & \multirow[t]{21}{*}{$98.8^{\mathrm{a}}$} & 1.40 & $<0.01$ \\
\hline Arg & & $88.7^{\mathrm{b}}$ & & $91.4^{\mathrm{b}}$ & $98.7^{\mathrm{a}}$ & & & 1.29 & $<0.01$ \\
\hline His & & $88.3^{\mathrm{b}}$ & & $88.3^{\mathrm{b}}$ & $98.5^{\mathrm{a}}$ & & & 1.47 & $<0.01$ \\
\hline Ile & & $89.7^{\mathrm{b}}$ & & $90.7^{\mathrm{b}}$ & $99.0^{\mathrm{a}}$ & & & 1.26 & $<0.01$ \\
\hline Leu & & $88.1^{\mathrm{c}}$ & & $92.0^{\mathrm{b}}$ & $99.5^{\mathrm{a}}$ & & & 1.33 & $<0.01$ \\
\hline Lys & & $88.8^{\mathrm{b}}$ & & $88.0^{\mathrm{b}}$ & $96.5^{\mathrm{a}}$ & & & 1.35 & $<0.01$ \\
\hline Met & & $88.9^{\mathrm{c}}$ & & $92.6^{\mathrm{b}}$ & $99.4^{\mathrm{a}}$ & & & 1.21 & $<0.01$ \\
\hline Phe & & $88.4^{\mathrm{b}}$ & & $90.0^{\mathrm{b}}$ & $98.9^{\mathrm{a}}$ & & & 1.36 & $<0.01$ \\
\hline Thr & & $88.3^{\mathrm{b}}$ & & $88.4^{\mathrm{b}}$ & $97.3^{\mathrm{a}}$ & & & 1.39 & $<0.01$ \\
\hline Trp & & $87.8^{\mathrm{c}}$ & & $92.6^{\mathrm{b}}$ & $95.5^{\mathrm{a}}$ & & & 1.27 & $<0.01$ \\
\hline Val & & $87.8^{b}$ & & $88.7^{\mathrm{b}}$ & $99.0^{\mathrm{a}}$ & & & 1.39 & $<0.01$ \\
\hline $\mathrm{EAA}^{4}$ & & $88.3^{\mathrm{b}}$ & & $90.1^{\mathrm{b}}$ & $98.8^{\mathrm{a}}$ & & & 1.35 & $<0.01$ \\
\hline Ala & & $88.4^{\mathrm{b}}$ & & $91.0^{\mathrm{b}}$ & $99.1^{\mathrm{a}}$ & & & 1.32 & $<0.01$ \\
\hline Asp & & $88.4^{\mathrm{b}}$ & & $90.0^{\mathrm{b}}$ & $98.5^{\mathrm{a}}$ & & & 1.33 & $<0.01$ \\
\hline Cys & & $88.4^{\mathrm{b}}$ & & $85.5^{\mathrm{b}}$ & $98.7^{\mathrm{a}}$ & & & 1.55 & $<0.01$ \\
\hline Glu & & $88.6^{\mathrm{c}}$ & & $92.3^{\mathrm{b}}$ & $99.4^{\mathrm{a}}$ & & & 1.29 & $<0.01$ \\
\hline Gly & & $88.4^{\mathrm{b}}$ & & $89.1^{\mathrm{b}}$ & $97.1^{\mathrm{a}}$ & & & 1.39 & $<0.01$ \\
\hline Pro & & $87.8^{b}$ & & $84.5^{\mathrm{b}}$ & $98.2^{\mathrm{a}}$ & & & 1.61 & $<0.01$ \\
\hline Ser & & $88.0^{\mathrm{b}}$ & & $88.8^{\mathrm{b}}$ & $98.8^{\mathrm{a}}$ & & & 1.36 & $<0.01$ \\
\hline Tyr & & $88.4^{\mathrm{b}}$ & & $89.8^{\mathrm{b}}$ & $98.9^{\mathrm{a}}$ & & & 1.36 & $<0.01$ \\
\hline $\mathrm{NEAA}^{5}$ & & $88.4^{\mathrm{b}}$ & & $89.7^{\mathrm{b}}$ & $98.9^{\mathrm{a}}$ & & & 1.38 & $<0.01$ \\
\hline \multicolumn{10}{|c|}{ Total-tract digestibility (\%) } \\
\hline DM & $99.9^{\mathrm{a}}$ & $90.4^{\mathrm{c}}$ & $98.9^{\mathrm{a}}$ & $80.3^{\mathrm{d}}$ & $81.4^{\mathrm{d}}$ & $98.5^{\mathrm{a}}$ & $95.1^{\mathrm{b}}$ & 0.67 & $<0.01$ \\
\hline $\mathrm{CP}$ & & $91.5^{\mathrm{d}}$ & & $93.5^{\mathrm{c}}$ & $97.6^{\mathrm{b}}$ & & $99.3^{\mathrm{a}}$ & 0.64 & $<0.01$ \\
\hline
\end{tabular}

${ }^{\mathrm{a}-\mathrm{d}}$ Means within a row with different superscript differ $(P<0.01)$.

${ }^{1}$ Residue recovered after intestinal incubation for BM1, BM3, SBM, and ESBM did not provide enough sample for analyses missing in this table.

${ }^{2} \mathrm{BM} 1, \mathrm{BM}$, and BM3 = blood meal from source 1, source 2, and source 3, respectively; $\mathrm{CM}=$ canola meal; LFDG = low-fat distillers dried grains with solubles; $\mathrm{SBM}=$ soybean meal; ESBM = expeller SBM.

${ }^{3}$ Treatment effect (feedstuff).

${ }^{4} \mathrm{EAA}=$ sum of Arg, His, Ile, Leu, Lys, Met, Phe, Thr, Trp, and Val.

${ }^{5} \mathrm{NEAA}=$ sum of Ala, Asp, Cys, Glu, Gly, Pro, Ser, and Tyr. 
Table 8. Intestinal absorbable dietary protein and intestinal absorbable AA supplied by RUP ${ }^{1}$

\begin{tabular}{|c|c|c|c|c|c|}
\hline \multirow{2}{*}{$\begin{array}{l}\text { Item } \\
(\% \text { of } \mathrm{CP})\end{array}$} & \multicolumn{3}{|c|}{ Feedstuff $^{2}$} & \multirow[b]{2}{*}{ SEM } & \multirow[b]{2}{*}{$P$-value ${ }^{3}$} \\
\hline & BM2 & $\mathrm{CM}$ & LFDG & & \\
\hline $\mathrm{IADP}^{4}$ & $61.7^{\mathrm{a}}$ & $17.9^{\mathrm{b}}$ & $20.7^{\mathrm{b}}$ & 2.73 & $<0.01$ \\
\hline Arg & $2.68^{\mathrm{a}}$ & $1.24^{\mathrm{b}}$ & $0.76^{\mathrm{c}}$ & 0.14 & $<0.01$ \\
\hline His & $3.80^{\mathrm{a}}$ & $0.46^{\mathrm{b}}$ & $0.39^{\mathrm{b}}$ & 0.12 & $<0.01$ \\
\hline Ile & $0.57^{\mathrm{b}}$ & $1.01^{\mathrm{a}}$ & $0.95^{\mathrm{a}}$ & 0.10 & $<0.01$ \\
\hline Leu & $8.55^{\mathrm{a}}$ & $1.77^{\mathrm{c}}$ & $3.59^{\mathrm{b}}$ & 0.37 & $<0.01$ \\
\hline Lys & $6.07^{\mathrm{a}}$ & $1.14^{\mathrm{b}}$ & $0.48^{\mathrm{c}}$ & 0.19 & $<0.01$ \\
\hline Met & $0.94^{\mathrm{a}}$ & $0.44^{\mathrm{b}}$ & $0.51^{\mathrm{b}}$ & 0.06 & $<0.01$ \\
\hline Phe & $4.80^{\mathrm{a}}$ & $1.04^{\mathrm{b}}$ & $1.40^{\mathrm{b}}$ & 0.18 & $<0.01$ \\
\hline Thr & $3.15^{\mathrm{a}}$ & $1.11^{\mathrm{b}}$ & $0.84^{\mathrm{b}}$ & 0.13 & $<0.01$ \\
\hline Trp & $0.77^{\mathrm{a}}$ & $0.25^{\mathrm{b}}$ & $0.13^{\mathrm{c}}$ & 0.04 & $<0.01$ \\
\hline Val & $5.95^{\mathrm{a}}$ & $1.32^{\mathrm{b}}$ & $1.15^{\mathrm{b}}$ & 0.23 & $<0.01$ \\
\hline $\mathrm{EAA}^{5}$ & $37.3^{\mathrm{a}}$ & $9.80^{\mathrm{b}}$ & $10.2^{\mathrm{b}}$ & 1.51 & $<0.01$ \\
\hline Ala & $5.15^{\mathrm{a}}$ & $1.09^{\mathrm{c}}$ & $1.94^{\mathrm{b}}$ & 0.21 & $<0.01$ \\
\hline Asp & $6.72^{\mathrm{a}}$ & $1.79^{\mathrm{b}}$ & $1.50^{\mathrm{b}}$ & 0.26 & $<0.01$ \\
\hline Cys & $0.62^{\mathrm{a}}$ & $0.37^{\mathrm{b}}$ & $0.34^{\mathrm{b}}$ & 0.04 & $<0.01$ \\
\hline Glu & $5.77^{\mathrm{a}}$ & $3.02^{\mathrm{c}}$ & $4.55^{\mathrm{b}}$ & 0.44 & $<0.01$ \\
\hline Gly & $2.62^{\mathrm{a}}$ & $1.10^{\mathrm{b}}$ & $0.74^{\mathrm{c}}$ & 0.14 & $<0.01$ \\
\hline Pro & $2.45^{\mathrm{a}}$ & $1.17^{\mathrm{c}}$ & $1.91^{\mathrm{b}}$ & 0.17 & $<0.01$ \\
\hline Ser & $2.99^{\mathrm{a}}$ & $0.97^{\mathrm{b}}$ & $1.02^{\mathrm{b}}$ & 0.13 & $<0.01$ \\
\hline Tyr & $1.86^{\mathrm{a}}$ & $0.74^{\mathrm{b}}$ & $0.96^{\mathrm{b}}$ & 0.10 & $<0.01$ \\
\hline NEAA $^{6}$ & $28.2^{\mathrm{a}}$ & $10.2^{\mathrm{b}}$ & $12.9^{\mathrm{b}}$ & 1.12 & $<0.01$ \\
\hline
\end{tabular}

${ }^{\mathrm{a}-\mathrm{c}}$ Means within a row with different superscript differ $(P<0.01)$.

${ }^{1}$ Intestinal absorbable AA supplied by RUP was calculated as $(100-\%$ ruminal degradation at $16 \mathrm{~h}) \times$ (intestinal digestibility coefficient) $\times$ AA concentration in the feed (Mjoun et al., 2010).

${ }^{2} \mathrm{BM} 2$ = blood meal from source $2 ; \mathrm{CM}=$ canola meal; LFDG = low-fat distillers dried grains with solubles.

${ }^{3}$ Treatment effect (feedstuff).

${ }^{4} \mathrm{IADP}=$ intestinal absorbable dietary protein, estimated by multiplying RUP by its intestinal digestibility.

${ }^{5} \mathrm{EAA}=$ sum of Arg, His, Ile, Leu, Lys, Met, Phe, Thr, Trp, and Val.

${ }^{6} \mathrm{NEAA}=$ sum of Ala, Asp, Cys, Glu, Gly, Pro, Ser, and Tyr.

supply to the animal. Microbial degradation of $\mathrm{CP}$ in the rumen changes the AA profile of the RUP of a feedstuff compared with its original profile. Bacterial CP contamination of the RUP was associated with NDF concentration of the feedstuff when using DNA as a bacterial marker but not when using purines. Correction for BCP contamination may be of more relevance in feedstuffs with high NDF content. The excessive rumen degradation of CP from LFDG observed in this study suggests that washout occurred and that bag techniques might not be adequate to evaluate this feedstuff. Across blood meals, BM2 was a better source of RUP. Compared with CM and LFDG, BM2 was a better source of intestinal absorbable dietary protein.

\section{ACKNOWLEDGMENTS}

The authors thank the employees of the University of Nebraska-Lincoln Dairy Research Facility for care and management of all experimental animals. Additional gratitude is expressed to the employees of Intermountain Farmers Association (Salt Lake City, UT) who collected and provided all samples used in this study.

\section{REFERENCES}

AOAC International. 1996. Official Methods of Analysis. 16th ed. AOAC International, Gaithersburg, MD.
AOAC International. 2000. Official Methods of Analysis. 17th ed. AOAC International, Gaithersburg, MD.

AOAC International. 2006. Official Methods of Analysis. 18th ed. AOAC International, Gaithersburg, MD.

ASABE (American Society of Agricultural and Biological Engineers). 2008. Method of determining and expressing fineness of feed materials by sieving. ANSI/ASAE S319.4. ASABE, St. Joseph, MI.

Beckers, Y., A. Théwis, B. Maudoux, and E. François. 1995. Studies on the in situ nitrogen degradability corrected for bacterial contamination of concentrate feeds in steers. J. Anim. Sci. 73:220-227.

Belanche, A., G. de la Fuente, D. R. Yáñez-Ruiz, C. J. Newbold, L. Calleja, and J. Balcells. 2011. Technical note: The persistence of microbial-specific DNA sequences through gastric digestion in lambs and their potential use as microbial markers. J. Anim. Sci. $89: 2812-2816$

Borucki Castro, S. I., L. E. Phillip, H. Lapierre, P. W. Jardon, and R. Berthiaume. 2007. Ruminal degradability and intestinal digestibility of protein and amino acids in treated soybean meal products. J. Dairy Sci. 90:810-822.

Boucher, S. E., S. Calsamiglia, C. M. Parsons, H. H. Stein, M. D. Stern, P. S. Erickson, P. L. Utterback, and C. G. Schwab. 2009. Intestinal digestibility of amino acids in rumen undegradable protein estimated using precision-fed cecectomized rooster bioassay: I. Soybean meal and SoyPlus. J. Dairy Sci. 92:4489-4498.

Britton, R. A., D. P. Colling, and T. J. Klopfenstein. 1978. Effect of complexing sodium bentonite with soybean meal or urea in vitro ruminal ammonia release and nitrogen utilization in ruminants. J. Anim. Sci. 46:1738-1747.

Broderick, G. A., and J. H. Kang. 1980. Automated simultaneous determination of ammonia and total amino acids in ruminal fluid and in vitro media. J. Dairy Sci. 63:64-75.

Broderick, G. A., and N. R. Merchen. 1992. Markers for quantifying microbial protein synthesis in the rumen. J. Dairy Sci. 75:2618 2632 . 
Castillo-Lopez, E., T. J. Klopfenstein, S. C. Fernando, and P. J. Kononoff. 2013. In vivo determination of rumen undegradable protein of dried distillers grains with solubles and evaluation of duodenal microbial crude protein flow. J. Anim. Sci. 91:924-934.

Castillo-Lopez, E., P. J. Kononoff, and J. L. Miner. 2010. Short communication: Detection of yeast DNA in omasal digesta of dairy cows consuming dried distillers grains and solubles. J. Dairy Sci. 93:5926-5929.

Clark, J. H., T. H. Klusmeyer, and M. R. Cameron. 1992. Microbial protein synthesis and flows of nitrogen fractions to the duodenum of dairy cows. J. Dairy Sci. 75:2304-2323.

Corrigan, M. E., T. J. Klopfenstein, G. E. Erickson, N. F. Meyer, K. J. Vander Pol, M. A. Greenquist, M. K. Luebbe, K. K. Karges, and M. L. Gibson. 2009. Effects of level of condensed distillers solubles in corn dried distillers grains on intake, daily body weight gain, and digestibility in growing steers fed forage diets. J. Anim. Sci. 87:4073-4081

DuBois, M., K. A. Gilles, J. K. Hamilton, P. A. Rebers, and F. Smith 1956. Colorimetric method for determination of sugars and related substances. Anal. Chem. 28:350-356.

Erasmus, L. J., P. M. Botha, C. W. Cruywagen, and H. H. Meissner 1994. Amino acid profile and intestinal digestibility in dairy cows of rumen-undegradable protein from various feedstuffs. J. Dairy Sci. 77:541-551.

Erwin, E. S., G. J. Marco, and E. M. Emery. 1961. Volatile fatty acid analyses of blood and rumen fluid by gas chromatography. J. Dairy Sci. 44:1768-1771.

Guinard, J., and H. Rulquin. 1994. Effects of graded amounts of duodenal infusions of lysine on the mammary uptake of major milk precursors in dairy cows. J. Dairy Sci. 77:3565-3576.

Harstad, O. M., and E. Prestlokken. 2001. Rumen degradability and intestinal indigestibility of individual amino acids in corn gluten meal, canola meal and fish meal determined in situ. Anim. Feed Sci. Technol. 94:127-135.

Howie, S. A., S. Calsamiglia, and M. D. Stern. 1996. Variation in ruminal degradation and intestinal digestion of animal byproduct proteins. Anim. Feed Sci. Technol. 63:1-7.

Hristov, A. N., and G. A. Broderick. 1996. Synthesis of microbial protein in ruminally cannulated cows fed alfalfa silage, alfalfa hay, or corn silage. J. Dairy Sci. 79:1627-1637.

Hristov, A. N., T. A. McAllister, D. R. Ouellet, and G. A. Broderick. 2005. Comparison of purines and nitrogen-15 as microbial flow markers in beef heifers fed barley- or corn-based diets. Can. J. Anim. Sci. 85:211-222.

Kang, Y. J., J. Cheng, L. J. Mei, J. Hu, Z. Piao, and S. X. Yin. 2010 Multiple copies of $16 \mathrm{~S}$ rRNA gene affect the restriction patterns and DGGE profile revealed by analysis of genome database. Microbiology 79:664-671.

Kelzer, J. M., P. J. Kononoff, L. O. Tedeschi, T. C. Jenkins, K. Karges, and M. L. Gibson. 2010. Evaluation of protein fractionation and ruminal and intestinal digestibility of corn milling co-products. J. Dairy Sci. 93:2803-2815.

Kononoff, P. J., S. K. Ivan, and T. J. Klopfenstein. 2007. Estimation of the proportion of feed protein digested in the small Intestine of cattle consuming wet corn gluten feed. J. Dairy Sci. 90:2377-2385.

Li, C., J. Q. Li, W. Z. Yang, and K. A. Beauchemin. 2012. Ruminal and intestinal amino acid digestion of distiller's grain vary with grain source and milling process. Anim. Feed Sci. Technol. 175:121-130.

Makkar, H. P. S., and K. Becker. 1999. Purine quantification in digests from ruminants by spectrophotometric and HPLC methods. Br. J. Nutr. 81:107-112.

Maxin, G., D. R. Ouellet, and H. Lapierre. 2013. Ruminal degradability of dry matter, crude protein, and amino acids in soybean meal, canola meal, corn, and wheat dried distillers grains. J. Dairy Sci. 96:5151-5160

McDougall, E. I. 1948. Studies on ruminant saliva. I. The composition and output of sheep's saliva. Biochem. J. 43:99-109.

Messman, M. A., and W. P. Weiss. 1994. Use of electrophoresis to quantify ruminal degradability of protein from concentrates feeds. Anim. Feed Sci. Technol. 49:25-35.

Meyer, B. E., C. L. Bouma, and J. C. MacDonald. 2012. Case study: In situ determination of protein digestibility of dried distillers grains containing 3 lipid concentrations using a mobile bag method. Prof. Anim. Sci. 28:678-681.

Michalet-Doreau, B., and M. Y. Ould-Bah. 1992. In vitro and in sacco methods for the estimation of dietary nitrogen degradability in the rumen: A review. Anim. Feed Sci. Technol. 40:57-86.

Mjoun, K., K. F. Kalscheur, A. R. Hippen, and D. J. Schingoethe. 2010. Ruminal degradability and intestinal digestibility of protein and amino acids in soybean and corn distillers grains products. J. Dairy Sci. 93:4144-4154.

Moya, D., S. Calsamiglia, A. Ferret, M. Blanch, J. I. Fandino, L. Castillejos, and I. Yoon. 2009. Effects of dietary changes and yeast culture (Saccharomyces cerevisiae) on rumen microbial fermentation of Holstein heifers. J. Anim. Sci. 87:2874-2881.

NRC. 2001. Nutrient Requirements of Dairy Cattle. 7th rev. ed. Natl. Acad. Press, Washington, DC.

O'Connor, J. D., C. J. Sniffen, D. G. Fox, and W. Chalupa. 1993. A net carbohydrate and protein system for evaluating cattle diets: IV. Predicting amino acid adequacy. J. Anim. Sci. 71:1298-1311.

Ogier, J. C., O. Son, A. Gruss, P. Tailliez, and A. Delacroix-Buchet. 2002. Identification of the bacterial microflora in dairy products by temporal temperature gradient gel electrophoresis. Appl. Environ. Microbiol. 68:3691-3701.

Paz, H. A., E. Castillo-Lopez, H. A. Ramirez-Ramirez, D. A. Christensen, T. J. Klopfenstein, and P. J. Kononoff. 2013. Invited review: Ethanol co-products for dairy cows: There goes our starch ... now what? Can. J. Anim. Sci. 93:407-425.

SAS Institute. 2008. SAS/STAT 9.2 User's Guide. SAS Institute Inc. Cary, NC.

Schwab, C. G. 2010. Balancing diets for amino acids: Nutritional, environmental and financial implications. Pages 1-13 in Proc. TriState Dairy Nutr. Conf., Ft. Wayne, IN. The Ohio State University, Columbus.

Schwab, C. G., C. K. Bozak, N. L. Whitehouse, and M. M. A. Mesbah. 1992. Amino acid limitation and flow to duodenum at four stages of lactation. 1. Sequence of lysine and methionine limitation. J. Dairy Sci. 75:3486-3502.

Van Amburgh, M. E., A. Foskolos, A. Collao-Saenz, R. J. Higgs, and D. A. Ross. 2013. Updating the CNCPS feed library with new feed amino acid profiles and efficiencies of use: Evaluation of moldel predictions-version 6.5. Pages 59-76 in Proc. 75th Cornell Nutrition Conference for Feed Manufacturers. Cornell University, Syracuse, NY.

Van Soest, P. J., J. B. Robertson, and B. A. Lewis. 1991. Methods for dietary fiber, neutral detergent fiber, and nonstarch polysaccharides in relation to animal nutrition. J. Dairy Sci. 74:3583-3597.

van Straalen, W. M., J. J. Odinga, and W. Mostert. 1997. Digestion of feed amino acids in the rumen and small intestine of dairy cows measured with nylon-bag techniques. Br. J. Nutr. 77:83-97.

Vanhatalo, A., and T. Varvikko. 1995. Effect of rumen degradation on intestinal digestion of nitrogen of $15 \mathrm{~N}$-labelled rapeseed meal and straw measured by the mobile-bag technique in cows. J. Agric. Sci. 125:253-261.

Vanzant, E. S., R. C. Cochran, and E. C. Titgemeyer. 1998. Standardization of in situ techniques for ruminant feedstuff evaluation. J. Anim. Sci. 76:2717-2729.

Yoon, I. K., K. J. Lindquist, D. D. Hongerholt, M. D. Stern, B. A Crooker, and K. D. Short. 1996. Methods of processing menhaden fish meal and their effects on ruminal protein degradation assessed by various techniques. Anim. Feed Sci. Technol. 60:13-27.

Yu, Y., C. Lee, J. Kim, and S. Hwang. 2005. Group-specific primer and probe sets to detect methanogenic communities using quantitative real-time polymerase chain reaction. Biotechnol. Bioeng. 89:670-679.

Yu, Z. T., and M. Morrison. 2004. Improved extraction of PCR-quality community DNA from digesta and fecal samples. Biotechniques $36: 808-812$

Zimmermann, M. B., C. Chassard, F. Rohner, E. K. N. Goran, C. Nindjin, A. Dostal, J. Utzinger, H. Ghattas, C. Lacroix, and R. F. Hurrell. 2010. The effects of iron fortification on the gut microbiota in African children a randomized controlled trial in Cote d'Ivoire. Am. J. Clin. Nutr. 92:1406-1415. 